\title{
Analysis of Online Portal and E-Payment Application Usage: A Case Study of BAZNAS Indonesia
}

\author{
Khairul Rijal \\ International Islamic University of Malaysia \\ Paper to be presented at International Conference of Zakat 2018 \\ 15-16 November, Universitas Gadjah Mada, Yogyakarta, Indonesia
}

\section{ABSTRACT}

The best achievement of zakat institutions in carrying out their duties as an organization is strongly influenced by several strategies of use in the latest technology in the current era. This statement is supported when we see some information dissemination, with various types of payment tools that can convert manual systems into online and electronic systems. Payment is the heart of business. For online businesses, electronic payments (E-payments) play an important role to accelerate every transaction of institutions. As we all know that there are various types of electronic payment systems available to facilitate online buying and selling transactions. This research will describe the current performance status of the National Zakat Agency website (BAZNAS) as well as identify several factors that contribute to improvement through analysis of survey results. The development website process often faces many difficulties that need to be addressed. Various important elements must be discussed to serve input that is useful for the webmaster as well as the institution itself so that it will make the website more effective as expected by the provider and recipient of information. Then this study tries to identify the type of electronic payment system in BAZNAS one of the Islamic philanthropic institutions in Indonesia and focuses on some background of the development of BAZNAS institutions, which have been preceded by an explanation of the duties and responsibilities of this zakat institution as the coordinator of zakat institutions in Indonesia. Then analyze the performance of electronic payments at the institution. The results of this study are expected to contribute to the body of knowledge, especially in terms of information technology and performance measurement in Islamic philanthropic institutions.

Keywords: Performance, Technology Development, Improvement

\section{INTRODUCTION}

Indonesia has a non-profit institution that focuses on poverty alleviation, namely the Amil Zakat Agency (BAZNAS) where the existence of BAZNAS is currently growing rapidly. BAZNAS has a great responsibility to hold the trust of the government and society towards the management of zakat in Indonesia. In this modern era, in terms of the achievement of existence in the zakat institution in carrying out its mandate as an organization is strongly influenced by a new strategy namely the use of contemporary technology. This statement is supported by government policies that focus on zakat and accelerating the increase of zakat performance. Then accompanied by the dissemination of information and various ways of payment that can turn traditional systems into online and electronic systems. 
Therefore, this paper will highlight some background of the development of zakat institutions, especially BAZNAS, which is preceded by an explanation of the duties and responsibilities of BAZNAS in Indonesia. Then, this paper will describe the current performance status of the BAZNAS website and then identify a number of factors that contribute to improvements through analysis of survey results. We need to be aware that in the process of developing a website, it often faces several obstacles that need to be resolved. Then various important elements must be explored to provide important input to the webmaster and the institution itself so that the output will make the website more effective and efficient in accordance with what is stated by religion. So that in the end we can find out how much potential increase in the amount of zakat collection in the coming year, so that it can be one of the main instruments of zakat in BAZNAS.

In accordance with the development of the world view of technological progress and the Internet as the latest major media. Therefore, there is a need to find out what factors can influence the use of online channels for the BAZNAS Portal to increase the collection of zakat funds in Indonesia. The purpose of this research is to find out the current internet usage scenario by the community in matters related to zakat and especially in terms of paying zakat through online. Finally, the research is expected to be used as a reference to BAZNAS to improve existing services to make it better, effective and efficient.

Next we will also highlight the effectiveness of zakat payments using an electronic payment system (e-payment). Currently the electronic payment system in Islamic philanthropic institutions has become an alternative for busy muzakki so they cannot pay zakat through manuals. The electronic payment applications applied by
BAZNAS include online banking, short messaging systems (SMS), telephone banking, ATMs and credit cards. Then this research tries to identify the type of electronic payment system then analyzes the performance of electronic payments in BAZNAS. The results of this study are expected to influence academics and practitioners and similar institutions in terms of information technology and performance measurement in BAZNAS.

This research is arranged as follows. Section 2 provides a review of the literature on the potential of website users and electronic payments of zakat and its administration in the contemporary economy. Section 3 provides details on the research methodology, including the sampling methodology and the methods we use to estimate the potential for zakat collection through zakat online portals and payments. Finally, section 4 presents the results of our analysis. We estimate and compare the potentials of zakat both in terms of promotion through portals and zakat online payments to alleviate poverty in Indonesia.

\section{LITERATURE REVIEW}

\section{Electronic Payment (E-Payment)}

Antwi, Hamza, and Bavoh (2015) define electronic payments as the transfer of payers from monetary claims on parties that can be accepted by profitable parties. Then another definition of E-payment is when a trader sells goods to a customer and the customer pays the price with the help of an E-Payment system. In offline transactions payments are made by cash or by check. Then in online sales receiving payment is the curial aspect of the transaction (Kaur M, 2012). In general, electronic payments are applied during online purchases, where validity, 
verification and approval are present simultaneously, where most transactions use e-banking, debit and credit cards.

In this case, electronic payments are not limited to credit cards, debit cards, emoney and internet banking alone but other media, such as payments through ATMs or bank counters, are also considered electronic payments. Although there are many types of payment options an electronics available as mentioned above, credit cards have difficulty with other instruments to go online. he traders sell goods to customers and customers pay prices with the help of an E-Payment system. In the offline world payments are made by cash or by check. In selling online receiving payment is an aspect of curation of transactions (Kaur M, 2012). Then the most popular understanding of ECommerce is based on an online perspective of the business carried out.

E-commerce has provided the ability to buy and sell products, information and services on the Internet and other online environments. For example in terms of any trading activity, the problem of safe and reliable exchange of money between the parties to the transaction is very important. In an e-commerce environment, payments take the form of electronic exchange of forms, and are therefore called Electronic Payments (Abrazhevich D \& Markopoulos, 2009). E-Payment Systems are secure. There should be no threat to users' credit card numbers, smart cards or other personal details, payments can be made without the involvement of third parties, it makes $\mathrm{E}$ payments anytime via the internet directly to the completion of transfers and establishes an E-business environment (Hossein B, 2002).

E-payment refers to the automatic process of exchanging monetary value between parties in a business transaction and the transmission of value to the Information and Technology Communication (ICT) network. Indonesia is the fastest growing cell phone country. Thus, Indonesia has great potential for the implementation of mobile commerce in addition to electronic commerce. There are at least 32 Electronic Money Providers that have obtained licenses from Bank Indonesia, this is a pretty good achievement compared to the number of Electronic Money providers the previous year.

Bank Indonesia states that the payment system in Indonesia is categorized by several groups such as card-based payment instruments (APMK) for example checks or bilyet giro, and payment instruments that use cards such as ATM cards, credit cards, debit cards, prepaid cards, BI-RTGS transfer systems and the Bank Indonesia national clearing system transfer system (SKNBI) The history of the development of electronic payment equipment in Indonesia has been applied by Bank Indonesia through the Bank Indonesia Real Time Gross Settlement (BIRTGS) system since 2000.

Then in line with the development of payment instruments, volume and value Transactions through non-cash payment instruments in paper-based, card-based and other electronic forms from year to year also almost always show an increasing trend. In 2008 a significant increase in the internetbased payment system was implemented as seen from Card-Based Payment Instrument (APMK) transactions. The latest cellularbased payment system emerged in mid2008. In Indonesia, there are 18 Amil Zakat institutions that have obtained permission from the Ministry of Religion. This is done to facilitate the community, especially Indonesian Muslims, to be able to distribute their zakat easily. Uniquely, each Zakat institution is assigned under the Ministry of Religion. 
Table 1. Zakat Institutions in Indonesia

\begin{tabular}{cl}
\hline No. & \multicolumn{1}{c}{ Zakat Institution } \\
\hline 1. & BAZNAS \\
2. & LAZ Rumah Zakat Indonesia \\
3. & LAZ Daarut Tauhiid \\
4. & LAZ Baitul Maal Hidayatullah \\
5. & LAZ Dompet Dhuafa Republika \\
6. & LAZ Nurul Hayat \\
7. & LAZ Inisiatif Zakat Indonesia \\
8. & LAZ Yatim Mandiri Surabaya \\
9. & LAZ Lembaga Manajemen Infak Ukhuwah \\
& Islamiyah \\
10. & LAZ Dana Sosial Al Falah Surabaya \\
11. & LAZ Pesantren Islam Al Azhar \\
12. & LAZ Baitulmaal Muamalat \\
13. & LAZIS-NU \\
14. & LAZ Global Zakat \\
15. & LAZ Muhammadiyah \\
16. & LAZ Dewan Dakwah Islamiyah Indonesia \\
17. & LAZ Perkumpulan Persatuan Islam \\
18. & LAZ Rumah Yatim Arrohman Indonesia \\
\hline
\end{tabular}

Source: BAZNAS

Thus, there are several differences between zakat practices in different countries. As mentioned earlier, one of the fundamental functions of these institutions is to collect zakat from Muslims who are eligible to pay various types of zakat. Traditionally, muzakki (zakat payers) pay zakat to amil (people who are officially appointed by zakat institutions to collect zakat) or zakat centers. Others prefer to pay directly to Asnaf (people who are entitled to receive zakat) (Ahmad et al., 2006). Implementation of information technology tools such as e-payment is not only discussed by businesses or profit-oriented companies, but non-profit organizations others include government institutions and philanthropic institutions due to various rationales, namely improving the quality of service, raising money, the performance and reputation of the institution itself.

Basically, the application of information technology tools in these institutions is not only fundamental in carrying out office and administrative tasks, but also in dealing with consumers in terms of financial administration. Through random observations of several zakat zakat websites in Indonesia, these institutions have introduced various types of online payments as an alternative for muzakki to carry out their obligations. Electronic payment applications by this institution include short message systems (SMS), e-banking, call banking, ATMs and credit cards. Online payment applications in these institutions are believed to benefit both parties, whether they are payers or recipients. In this case, there are limited studies conducted on philanthropic activities such as online payment, especially in Islamic philanthropic activities such as Zakat, Infaq, Alms and Endowments (ZISWaf).

There is no evidence to show that the phenomenon and its contribution to ZISWaf provide collections to philanthropic institutions. The benefits of online payments are expected to increase the collection of Zakat and cash Waqf as a Zakat payment system. Thus, this study wishes to further explore the types of electronic payments offered by BAZNAS Indonesia. Then, aims to analyze zakat collection under each type of electronic payment method. Information is collected through the institution's website, Instagram, Twitter, Facebook and mass media owned by this institution. This research is expected to provide input for other non-profit organizations such as DT Peduli Zakat Institution, Dompet Dhuafa, Rumah Zakat, IZI and others, especially in utilizing internet tools to optimize their zakat collection. Then it can be a reference in terms of electronic payments for nonprofit organizations in Indonesia. Zakat Institution Services Since the inception of BAZNAS has introduced various services with the aim of encouraging Muslims to hasten their zakat obligations.

Year after year BAZNAS has carried out development by introducing several 
types of zakat that can be collected such as: zakat on income, business, stocks, gold, silver and several other types, especially in Indonesia. Renewal and continuous improvement approaches are expected to facilitate muzakki. Until now, new types of payment channels have been implemented in Indonesia such as deductions from salaries of civil servants, through bank counters, post office counters, Zakat Collection Units, internet portals and so on. The development of payments from most of the available channels has clearly reflected the needs of the channel. Internet portal socialization as a zakat payment channel began in 2015. Thus the payment channel method will have an impact on the increase in the amount of zakat collection. The proof of improvement can be shown below: In improving the payment process that is more effective and efficient, a system that can be done using online is through an online payment channel.

Based on a statement from Adnan Mohammad (2008), the development of epayments can help improve the efficiency of the financial system by reducing transaction costs and increasing liquidity and providing better allocation of financial resources that can bring many benefits to all parties in the financial sector.

On the other hand, the application of online services can also reduce operational costs such as marketing costs and wage costs. The concept of payment is manual and still traditional, resulting in agencies attempting several ways to use technology. The aim of innovating is to provide the best service to customers. The most important part of technological innovation in end-user relationships is fast response, cash register technology, and Self-Service Technologies (SSTs) such as vending machines and multimedia sales kiosks at a distance (especially on-line sales), electronic and cellular payment systems. Renewing online technology will have an impact on the operational form of the channel system by developing the level at which member tasks and resources need to be integrated. Proper use of software requires the integration of channel operations in a larger, centralized and standardized manner.

\section{RESEARCH FINDINGS AND DISCUSSIONS}

Through surveys conducted, research found that various factors that must be improved in the process of developing and improving zakat websites are that each element outlined must be considered important to meet the needs of the community such as a rapid response in this case, for example: prospective donors ask about process or mechanism to pay zakat. It is preceded by a search engine system, where BAZNAS occupies the top position, then other mass media such as Instagram, Facebook, Twitter, and others. Then through print media such as posters, newspapers, pamphlets, advertisements and printed materials and so on. In the end, the implementer must make the search engine and advertising system as a means to socialize the portal to get more internet surfers. In this case the author believes this finding can also be used as a reference with other websites of other zakat countries.

\section{RESEARCH METHODOLOGY}

Information is collected from primary data. The data involved 107 respondents from zakat payers who had paid zakat through electronic payment channels and obtained information through BAZNAS online media. The time period for receiving feedback is in 2017. While the secondary data is based on information from BAZNAS 
Annual Report. Then the author uses secondary data. Kumar et al. (2013) explained that secondary data refers to information that has been prepared by other parties and is available to researchers. This data can be internal or external and can be accessed via the internet or read information recorded or published.

Therefore, data is collected through information available on the website, Facebook and print media websites. In addition, data is directly provided by employees of this institution. Then the purpose of the analysis, this study uses a quantitative research approach. Findings For the purpose of collecting zakat, this zakat institution offers twelve types of payment options to zakat payers, both online and offline. Payment of offline or manual zakat is available at this institution; counters located in several districts in the state, by post, payroll deductions, bank counters, temporary / moving counters and through 'Amils' Certified.

For electronic payments, there are six options offered by institutions including internet banking, short message systems (SMS), phone banking, kiosk machines, credit cards and bank card ATMs. Zakat Collection by Type of E-Payment Overall, the number of Zakat payers uses internet banking, bank ATM cards and credit cards increase every year. This shows that internet banking has flooded other types of electronic payments every year, with a total of 7,304 payers over five years; represents $61.2 \%$ of online payments. This was followed by bank card ATMs (3,165 payers) and credit cards (1,225 payers). For this period also, there is no Zakat payer for telephone banking. Since kiosk12 machines have just been introduced in 2014, the total Zakat payers are only 228 .

However, compared to SMS and telephone banking methods, kiosk machine prices are far better and have the potential to increase in the future. Discussion The findings indicate that the e-payment system is becoming more popular in Malaysia (Mohammad, 2008). Although the amount of zakat collected and the percentage of increase remains low compared to offline payments, there is still room for improvement because IT is growing rapidly combined with the fact that taxpayers are now more IT literate.

In addition, this finding also supports the study conducted by Basir (2009) and Abdullah et al (2012) where they claim that Malaysians prefer to use credit cards and internet banking when they make online payments. Compared to other countries, bank cards are one of the most popular electronic payment methods among Muslims in Malaysia which is similar to the situation in Germany (Turban, et.al, 2011). The authors found that even though their clients preferred to pay Zakat directly to this institution, they chose to pay with a credit card for electronic payments. This trend is similar to the findings of Adeyeye (2008) who conducted research on electronic payments in Nigeria and other researchers including Hsieh (2001), Paynter and Lim, (2001) and Jan Wong (2013). This study also confirms research conducted by Abdul Lateff et al. (2014) and data provided by PZNS (2014) where Zakat collections increased each year from 2009 to 2014 although they did not explain the payment method.

However, even though e-payment contributions are insignificant, it can be a factor for the addition of Zakat collections in addition to privatization, increasing awareness among zakat payers, increasing individual income and increasing state revenues as suggested by Nor Ghani et al. (As quoted by Ahmad et al., 2006). Finally, an analysis of the findings also supports research conducted by Abd. Wahab and Abdul Rahman (2013) where they stated that 
online payments would increase the collection of Zakat and cash waqf as a payment system for Zakat and a computerized Zakat system is one of the determining factors affecting the efficiency of zakat institutions.

\section{GENERAL FACT FOR REASONS TO PAY ZAKAT USING CHANNELS BAZNAS ONLINE PAYMENT THE MAIN FACTOR PAYING ZAKAT THROUGH THE WEBSITE:}

1) To make efficiency and effectiveness and facilitate the payment process.

2) Time savings. Two factors greatly meet the main objectives of the online portal channel created to facilitate the difficulties of the community to make payments through other channels, and help them save time. Another factor that is no less important in contributing is factor

3) Availability of information, which has many explanations and answers to problems and methods of calculating zakat (calculator) provided;

4) Cyber security factors are very important and must be guaranteed at all times.

5) Website design does not contribute to the receipt of payment channels, but should not be ignored equally once because to a certain degree shows the level of professionalism of the zakat institution in managing their website.

Based on the results and discussion, this paper looks at some elements that can be incorporated into the operational management of the zakat institution's website. In creating an effective website, the development process must be in accordance with the current scenario and the use of the internet by the public. Several proposals are outlined, namely: Accessible. Web sites must be easily accessible and can be easily found, especially through search engine systems. This is because, opening up more opportunities for internet surfers to find sites that are needed, so that they have the potential to become customers. Among others, it also helps in the process of propagation and dissemination of information to the community along with the obligatory zakat institution itself which has the duty to explain the importance and ways of doing zakat.

Matches the main and popular devices. Every website must be developed according to the views of the most popular devices that are computers. But it does not necessarily rule out the future of highpotential devices such as smartphones and tablets. This is because an increase in the use of this device must be considered important. Thus, the task of building an effective and appropriate application (application) must be done immediately so that the Muslim community learns about zakat. The intermediate language contained on the website must be diversified and not limited to Indonesian and English. With the diversity of languages used, more visitors can get information about zakat especially attracting visitors from abroad. Constantly updated information Presented and updated information regularly. This is one important factor that will differentiate visitors into paying zakat or just pure internet surfers.

Availability information that is constantly updated is to show that the website is effective, efficient, and more user-friendly. Simple but attractive design Website design must be attractive but simple because it will help shorten download time. Such a fact is to attract people to trace and approach these sites. Web page management especially in terms of its size must be small so that it will efficiently prevent users from facing difficulties, especially those with slow internet bandwidth connections. 
Making the goal of establishment The most important factor is that each web page development and zakat increase must be anchored to facilitate the payment of zakat from customers. This is because online channels must be established to facilitate the difficult community of zakat through other channels. It does not only facilitate individuals and communities, but also companies, banks and entrepreneurs.

All payment transactions, registrations, questions, and all other related things must and can be done quickly and easily. Conclusion The development system of the PPZ or UPZ website is recognized to attract the Muslim community to do zakat which can be seen from the total collection achievement. The IT system has been seen as a medium of communication and information plays an important role in disseminating information and promoting zakat. Last but not least it is an important media in the process of collecting zakat. The website, for example, will gradually become the main driver in the process of disseminating information and payment instruments, by zakat institutions do not consider this technology only as a side activity. It is time for zakat institutions to increase the use of technology and the internet in all matters that all Muslims are able to fulfill their duties.

\section{CONCLUSION}

Until now there are many options in terms of offline or online payment methods available to zakat payers in Indonesia. Along with the progress in electronic payment mode, making muzakki no reason to escape zakat. Electronic payments are believed to be able to overcome some of the major obstacles in the payment of zakat effectively and efficiently such as time, distance, and others. Based on the results of the questionnaire survey that was distributed by the author, managed to collect 107 respondents and some secondary data from the BAZNAS Indonesia revealed that the bank card, internet banking and credit cards are one of the most popular electronic payment systems among institutional customers. Although the number of zakat collection and the number of payers is low compared to the offline method, there has been a gradual increase.

In addition, the author believes that electronic payments can be considered as one of the factors that contribute to the increase in zakat collections in Indonesia and other non-profit institutions because electronic payments offer various benefits to payers and recipients. Last but not the least, because studies in this field are very limited, this paper is expected to be able to explain to the knowledge body especially in terms of zakat and electronic payment. In addition, this paper provides input for other non-profit institutions. The PPZ website development system is recognized as interested in the Muslim community to do zakat which can be seen from the total achievement of the collection. Information technology systems have been seen as a medium of communication and information plays an important role in disseminating information and promoting zakat. Then the media is important in the process of collecting zakat.

Based on surveys and interviews that the website interface is quite dense, so what should be prioritized for promotion is less effective and efficient. With current technological advances it is very effective and efficient if agencies can use it well. Then it will gradually become the main driver in the process of disseminating information and payment instruments, by zakat institutions should not consider this technology only as a mere side activity. It is time for zakat institutions to increase the use of technology and the internet in all matters 
that can be done by all Muslims to fulfill their duties.

\section{SUGGESTIONS}

Synergy between all zakat stakeholders. Harmonious synergy needs to be strengthened among all zakat stakeholders; BAZNAS, LAZ, Ministry of Religion, Regional Government, Islamic community organizations, educational institutions, and other zakat stakeholders. Synergy is needed to realize the goals of zakat management as mentioned above, so that zakat can play a significant role in the life of the nation and state, and especially in realizing the welfare of society. Synergy that includes the synergy of heart, mind and charity, is ultimately expected to be a force that drives the progress in that country.

\section{REFERENCES}

Antwi, S. K., Hamza, K., \& Bavoh, S. W. (2015). Examining the Effectiveness of Electronic Payment System in Ghana: The Case of e-ZWICH in the Tamale Metropolis. Research Journal of Finance and Accounting, 6 (2), 163-177.

Mohamad, A., Haroon, A. \& Najiran, A. (2009). Development of Electronic Money and its Impact on the Central Bank Role and Monetary Policy. Issues in Information Science and Information Technology. 6 (1), 339344

Mohammad Auwal Kabir, Siti Zabedah Saidin, Aidi Ahmi. (2015) Adoption of e-Payment Systems: A Review of Literature. School of Accountancy, Universiti Utara Malaysia.
Muhsin Nor Paizin. (2017). The Unit of Islamic Alms's Online Portal: Case Study on Center for Zakat Collection, Federal Territories of Malaysia

www.baznas.go.id

www.bps.com

Khairul Rijal

International Islamic University of Malaysia Malaysia

khairulrijalphd@gmail.com 